\title{
Optimization of a multi-objective location model of manufacturing base considering cooperative manufacturing capabilities and service benefits
}

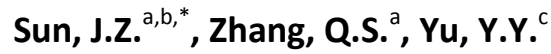 \\ ${ }^{\text {a }}$ School of Management, Shenyang University of Technology, Shenyang, P.R. China \\ ${ }^{\mathrm{b}}$ School of Management, Liaoning Institute of Science and Technology, Benxi, P.R. China \\ 'School of Management, Jinan University, Guangzhou, P.R. China
}

\begin{abstract}
A B S T R A C T
Improving customer satisfaction and shortening the manufacturing cycle have become common concerns of current manufacturers. This paper presents a multi-objective location model considering the maximization of collaborative manufacturing capabilities and service benefits. This method first uses the two dimensions of customer share and market consumption to segment customers, and identify the weight of various customer groups. Secondly, the space vector model (VSM) is used to calculate the matching between manufacturing capabilities and manufacturing requirements. Then build a multiobjective location model based on the two goals of collaborative manufacturing capabilities and service benefits. Finally, the model was tested with simulation data, which proved the validity and feasibility of the model. According to the simulation results, managers can accurately select the optimal manufacturing base from multiple candidate manufacturing bases with regard to less costs, shorter lead times, better manufacturing capabilities, better service benefits. In this paper, Fuzzy theory, Logit model and VSM are combined to salve the problem of manufacturing base location. Considering resources and service benefits of each manufacturing base, it is helpful to optimize the location of enterprises. From the academic and practical points, this study provides a new perspective for the location problem.
\end{abstract}

\section{ARTICLE INFO}

Keywords

Manufacturing base;

Location model;

Multi-objective model;

Optimization;

Decision-making;

Customer demand preference;

Collaborative manufacturing

*Corresponding author: bxsunjianzhu@163.com (Sun, J.Z.)

Article history:

Received 2 February 2021

Revised 22 February 2021

Accepted 28 February 2021

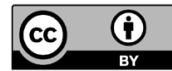

Content from this work may be used under the terms of the Creative Commons Attribution 4.0 International Licence (CC BY 4.0). Any further distribution of this work must maintain attribution to the author(s) and the title of the work, journal citation and DO

\section{References}

[1] Ocampo, L.A., Himang, C.M., Kumar, A., Brezocnik, M. (2019). A novel multiple criteria decision-making approach based on fuzzy DEMATEL, fuzzy ANP and fuzzy AHP for mapping collection and distribution centers in reverse logistics, Advances in Production Engineering \& Management, Vol. 14, No. 3, 297-322, doi: 10.14743/ apem2019.3.329.

[2] Medic, N., Anisic, Z., Lalic, B., Marjanovic, U., Brezocnik, M. (2019). Hybrid fuzzy multi-attribute decision making model for evaluation of advanced digital technologies in manufacturing: Industry 4.0 perspective, Advances in Production Engineering \& Management, Vol. 14, No. 4, 483-493, doi: 10.14743/apem2019.4.343.

[3] Marković, G., Zdravković, N., Karakašić, M., Kolarević, M. (2020). Modified PROMETHEE approach for solving multi-criteria location problems with complex criteria functions, Tehnički Vjesnik - Technical Gazette, Vol. 27, No. 1, 12-19, doi: $10.17559 /$ TV-20190225151515.

[4] Fazlollahtabar, H. (2021). A DSS-based dynamic programming for finding optimal markets using neural networks and pricing, Iranian Journal of Management Studies, Vol. 14, No. 1, 87-106, doi: 10.22059/ijms.2020. $\underline{269091.673397 .}$. 
[5] Hajibaba, H., Grün, B., Dolnicar, S. (2019). Improving the stability of market segmentation analysis, International Journal of Contemporary Hospitality Management, Vol. 32, No. 4, 1393-1411, doi: 10.1108/IJCHM-02-2019-0137.

[6] Chen, Y. (2017). Integrated and intelligent manufacturing: Perspectives and enablers, Engineering, Vol. 3, No. 5, 588-595, doi: 10.1016/I.ENG.2017.04.009.

[7] Tan, C., Chung, H., Barton, K., Jack Hu, S., Freiheit, T. (2020). Incorporating customer personalization preferences in open product architecture design, Journal of Manufacturing Systems, Vol. 56, 72-83, doi: 10.1016/i.jmsy.2020. $\underline{05.006}$.

[8] Wu, Q., Liao, K., Deng, X., Marsillac, E. (2020). Achieving automotive suppliers' mass customization through modlarity: Vital antecedents and the valuable role and responsibility of information sharing, Journal of Manufacturing Technology Management, Vol. 31, No. 2, 306-329, doi: 10.1108/JMTM-12-2018-0459.

[9] Han, S.Y. (2016). Convention Market Segmentation by the Attributes of Convention Site Selection - On the Subject of Professional Convention Organizers (PCO), Seoul Studies, Vol. 17, No, 4, 111-129.

[10] Zheng, X., Wu, C., He, S. (2020). Impacts of market segmentation on the over-capacity of the thermal electricity generation industry in China, Journal of Environmental Management, Vol. 279, Article No. 111761, doi: 10.1016/ j.jenvman.2020.111761.

[11] Lee, H. (2019). Analysis of location and site planning preference of USFK residential housing, Journal of the Korea Academia-Industrial cooperation Society, Vol. 20, No. 12, 822-827, doi: 10.5762/KAIS.2019.20.12.822.

[12] Ghorui, N., Ghosh, A., Algehyne, E.A., Mondal, S.P., Saha, A.K. (2020). AHP-TOPSIS inspired shopping mall site selection problem with fuzzy data, Mathematics, Vol. 8, No. 8, Article No. 1380, doi: 10.3390/math8081380.

[13] Jelokhani-Niaraki, M., Malczewski, J. (2015). A group multicriteria spatial decision support system for parking site selection problem: A case study, Land Use Policy, Vol. 42, 492-508, doi: 10.1016/j.landusepol.2014.09.003.

[14] Yoseph, F., Malim, N.H.A.H., Heikkilä, M., Brezulianu, A., Geman, O., Rostam, N.A.P. (2020). The impact of big data market segmentation using data mining and clustering techniques, Journal of Intelligent \& Fuzzy Systems, Vol. 38, No. 5, 6159-6173, doi: 10.3233/JIFS-179698.

[15] Samani, Z.N., Karimi, M., Alesheikh, A.A. (2018). A novel approach to site selection: Collaborative multi-criteria decision making through geo-social network (Case study: Public parking), ISPRS International Journal of GeoInformation, Vol. 7, No. 3, Article No. 82, doi: 10.3390/ijgi7030082.

[16] Wang, P., Liu, W., Lin, Z., Wen, F., Dong, Z., Zheng, Y., Zhang, R. (2017). Scenario analysis based collaborative site selection planning of wind farms and power-to-gas plants, Automation of Electric Power Systems, Vol. 41, No. 6, 20-29, doi: 10.7500/AEPS20161012007.

[17] Au, K.F., Wong, W.K., Zeng, X.H. (2006). Decision model for country site selection of overseas clothing plants, International Journal of Advanced Manufacturing Technology, Vol. 29, No. 3-4, 408-417, doi: 10.1007/s00170005-2505-4.

[18] García, J.L., Alvarado, A., Blanco, J., Jiménez, E., Maldonado, A.A., Cortés, G. (2014). Multi-attribute evaluation and selection of sites for agricultural product warehouses based on an Analytic Hierarchy Process, Computers and Electronics in Agriculture, Vol. 100, 60-69, doi: 10.1016/i.compag.2013.10.009.

[19] Cai, T., Wang, S., Xu, Q. (2015). Monte Carlo optimization for site selection of new chemical plants, Journal of Environmental Management, Vol. 163, 28-38, doi: 10.1016/i.jenvman.2015.08.002.

[20] Habibi, F., Asadi, E., Sadjadi, S.J., Barzinpour, F. (2017). A multi-objective robust optimization model for siteselection and capacity allocation of municipal solid waste facilities: A case study in Tehran, Journal of Cleaner Production, Vol. 166, 816-834, doi: 10.1016/j.jclepro.2017.08.063.

[21] Awaga, A.L., Xu, W., Liu, L., Zhang, Y. (2020). Evolutionary game of green manufacturing mode of enterprises under the influence of government reward and punishment, Advances in Production Engineering \& Management, Vol. 15, No. 4, 416-430, doi: 10.14743/apem2020.4.375.

[22] Li, H.-Y., Xu, W., Cui, Y., Wang, Z., Xiao, M., Sun, Z.-X. (2020). Preventive maintenance decision model of urban transportation system equipment based on multi-control units, IEEE Access, Vol. 8, 15851-15869, doi: 10.1109/ ACCESS.2019.2961433.

[23] Shapiro, A.F., Koissi, M.-C. (2017). Fuzzy logic modifications of the analytic hierarchy process, Insurance: Mathematics and Economics, Vol. 75, 189-202, doi: 10.1016/j.insmatheco.2017.05.003.

[24] Guadagni, P.M., Little, J.D.C. (2008). Commentary - A logit model of brand choice calibrated on scanner data: A $25^{\text {th }}$ anniversary perspective, Marketing Science, Vol. 27, No. 2, 26-28, doi: 10.1287/mksc.1070.0345.

[25] Shao, W., Ding, H., Tang, J., Peng, S. (2018). A data-driven optimization model to collaborative manufacturing system considering geometric and physical performances for hypoid gear product, Robotics and ComputerIntegrated Manufacturing, Vol. 54, 1-16, doi: 10.1016/j.rcim.2018.05.004.

[26] Jian, J., Wang, M., Li, L., Su, J., Huang, T. (2019). A partner selection model for collaborative product innovation from the viewpoint of knowledge collaboration, Kybernetes, Vol. 49, No. 6, 1623-1644, doi: 10.1108/K-05-20180266. 


\section{APEM}

Advances in Production Engineering \& Management
ISSN 1854-6250

Spletna stran: apem-journal.org Izvirni znanstveni članek

\title{
Optimizacija večkriterijskega modela lokacije proizvodne baze ob upoštevanju sodelujočih proizvodnih zmogljivosti in storitvenih ugodnosti
}

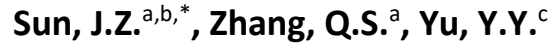 \\ aSchool of Management, Shenyang University of Technology, Shenyang, P.R. China \\ bSchool of Management, Liaoning Institute of Science and Technology, Benxi, P.R. China \\ 'School of Management, Jinan University, Guangzhou, P.R. China
}

\section{POVZETEK}

Dandanes želijo proizvajalci izboljšati zadovoljstvo strank in skrajšati proizvodni cikel. Ta članek predstavlja večkriterijski lokacijski model, ki upošteva maksimiranje sodelujočih proizvodnih zmogljivosti in storitvenih ugodnosti. Za segmentacijo kupcev in ugotavljanje pomembnosti različnih skupin kupcev metoda najprej uporabi dve razsežnosti: delež kupcev in tržno porabo. Nato je uporabljen model prostorskih vektorjev (VSM) za izračun ujemanja med proizvodnimi zmogljivostmi in proizvodnimi zahtevami. V nadaljevanju je zgrajen večkriterijski lokacijski model, ki temelji na dveh ciljih, in sicer skupni proizvodni zmogljivosti in storitvenih ugodnostih. Na koncu je bil model testiran s simulacijskimi podatki, ki so dokazali veljavnost in izvedljivost modela. Glede na rezultate simulacije lahko menedžerji natančno izberejo optimalno lokacijo proizvodne baze izmed več možnih proizvodnih baz z upoštevanjem nizkih stroškov, krajših dobavnih rokov, boljšo proizvodno zmogljivost in ugodnejše storitve. Da bi rešili težavo lokacije proizvodne baze so v tem članku združeni mehka logika, model Logit in VSM. Glede na vire in storitvene ugodnosti vsake proizvodne baze je koristno optimizirati lokacijo podjetij. Z akademskega in praktičnega vidika ta študija ponuja nov pogled na problematiko izbire lokacije.

\section{PODATKI O ČLANKU}

Ključne besede:

Proizvodna baza;

Lokacijski model;

Večkriterijski model;

Optimizacija;

Odločanje;

Preferenca povpraševanja strank;

Sodelujoča proizvodnja

*Kontaktna oseba:

bxsunjianzhu@163.com

(Sun, J.Z.)

Zgodovina članka:

Prejet 2. februarja 2021

Popravljen 22. februarja 2021

Sprejet 28. februarja 2021

\section{(i)}

Content from this work may be used under the terms of the Creative Commons Attribution 4.0 International Licence (CC BY 4.0). Any further distribution of this work must maintain attribution to the author(s) and the title of the work, journal citation and DOI. 